\title{
Case Study on Architecture of Lotus Temple
}

\author{
Er. Mohammed Sahil ${ }^{1}$, Er. Prafull Kothari ${ }^{2}$ \\ ${ }^{1}$ Civil Site Engineer, Parikshan Laboratory Material Testing Solutions, Indore, M.P. India \\ ${ }^{2}$ Assistant Professor, Department of Civil Engineering, SS College of Engineering, Udaipur Rajasthan, India
}

\begin{abstract}
This Paper is the case study of the architecture of lotus temple. In this paper the details about the lotus temple (general detail) and the architectural and structural study of lotus temple how to construct lotus temple, which type of problem/challenges arises during construction and the study of structural drawings.
\end{abstract}

Key Word: - Lotus Temple, Project Details, Topography, Concept, Construction System, Structural Details, Concrete, Reinforcement, Construction Challenges

\section{INTRODUCTION}

The Lotus temple is due to its flowerlike shape. Lotus temple is also known by the "BAHAI House of worship/ BAHAI FAITH". The Temple are well known for their architectural splendour and the temple constructed in Delhi is a continuation of this rich tradition. This is prominent attraction in Delhi. It was completed in 1986 and serves as the mother temple of the India subcontinent. The temple structure like as the half open lotus flower, afloat surrounded by its leaves. The temple is open to people of all cultures, faiths, and languages. It is the symbol of a United India.

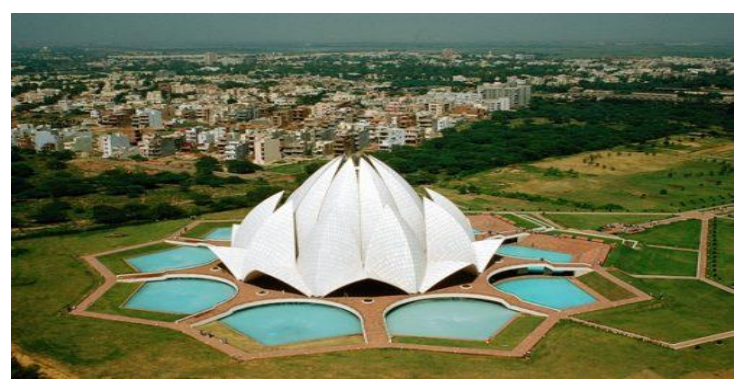

Fig: 1 Lotus Temple

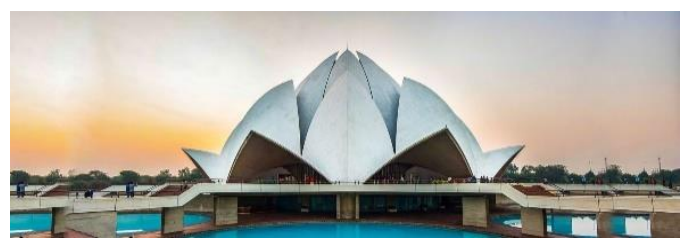

Fig: 2 Lotus Temple

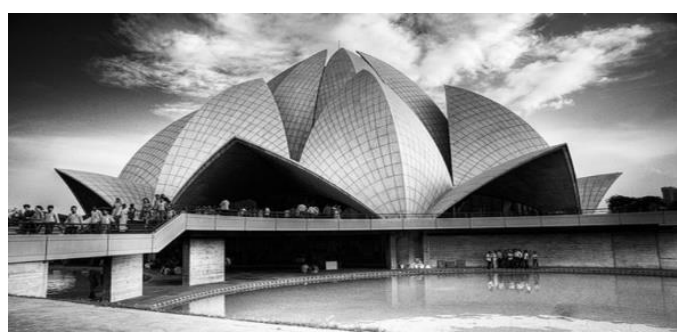

Fig: 3 Lotus Temple

\section{DETAILS ABOUT LOCATION}

The temple was constructed in the village of Bahapur, kalkaji, in south of New Delhi and to the west of Connaught place in Mandir Marg; a secluded area of busting centre of India's capital.

\section{PROJECT DETAILS}

\begin{tabular}{|c|c|c|}
\hline S.No. & Details & Details \\
\hline 1. & Architect & Fariburz Sahba \\
\hline 2. & $\begin{array}{l}\text { Structural } \\
\text { Designer }\end{array}$ & $\begin{array}{l}\text { Flint \& Nail } \\
\text { Flint and Nail } \\
\text { partnership } \\
\text { London were the } \\
\text { consultants }\end{array}$ \\
\hline 3. & Designed in & 1976 \\
\hline 4. & $\begin{array}{ll}\text { Designed } & \text { For } \\
\text { (In Year) } & \end{array}$ & 200 Year \\
\hline 5. & $\begin{array}{ll}\text { Built } & \text { Time } \\
\text { Period } & \end{array}$ & $1978-1986$ \\
\hline 6. & Constructed By & $\begin{array}{l}\text { ECC Construction } \\
\text { (Group of Larsen \& } \\
\text { Toubro Limited } \\
\text { were the contractors } \\
\text { responsible for } \\
\text { constructing the } \\
\text { lotus temple.) }\end{array}$ \\
\hline 7. & Total site area & $\begin{array}{l}24 \text { ACRES/105000 } \\
\text { SQ.M. }\end{array}$ \\
\hline 8. & $\begin{array}{l}\text { Setting } \\
\text { capacity }\end{array}$ & 1300 people \\
\hline 9. & Climate: & $\begin{array}{lr}\text { Tropical with great } \\
\text { variations } \\
\text { temperature }\end{array}$ \\
\hline 10. & $\begin{array}{l}\text { Building type } \\
\text { time of } \\
\text { construction }\end{array}$ & Worship place \\
\hline
\end{tabular}




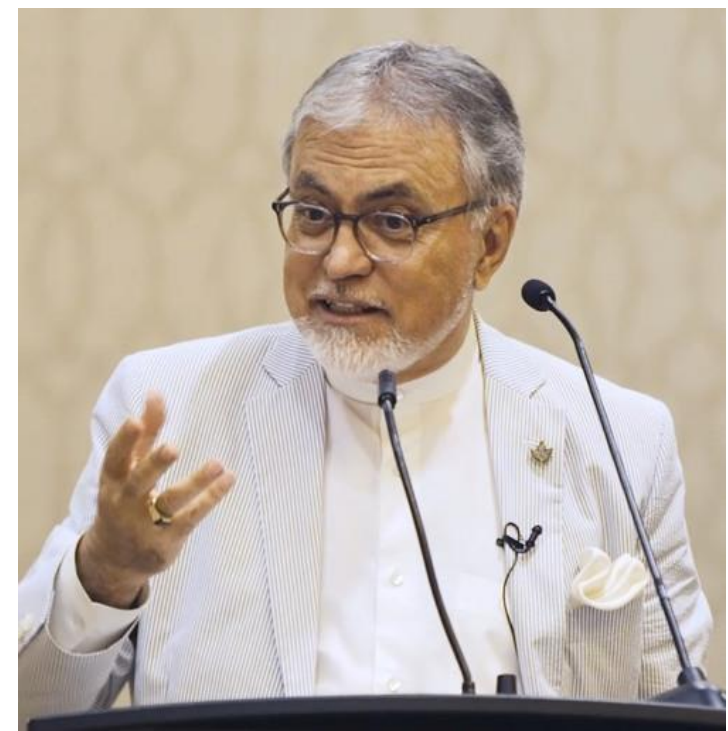

Fig: 4. Architect: - Fariburz Sahba

\begin{tabular}{|l|l|l|}
\hline S.No. & Details & Details \\
\hline 1. & Architect & Fariburz Sahba \\
\hline 2. & Born on & $\begin{array}{l}\text { January 01, 1948 (72 } \\
\text { years old). }\end{array}$ \\
\hline 3. & Designation & $\begin{array}{l}\text { Architect and project } \\
\text { manager }\end{array}$ \\
\hline 4. & Education & $\begin{array}{l}\text { He graduated } \\
\text { from University Of } \\
\text { Tehran }\end{array}$ \\
\hline 5. & $\begin{array}{l}\text { Project Duration } \\
\text { (Lotus Temple) }\end{array}$ & \begin{tabular}{l}
10 years \\
\hline
\end{tabular}
\end{tabular}

[Architect's travel throughout India for proper design]

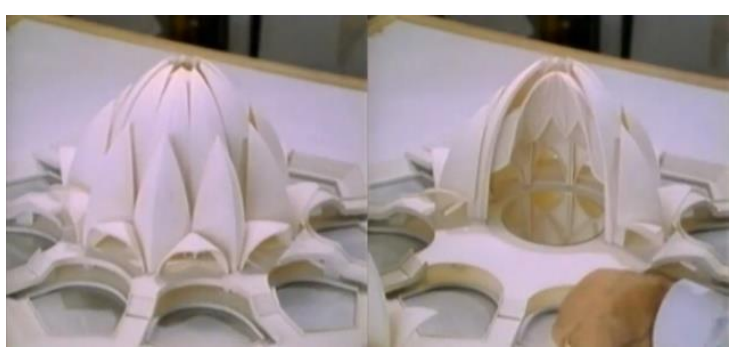

Fig: 5. Model of the Lotus Temple

\section{TOPOGRAPHY}

- The Lotus Temple site is sloping down naturally towards north east direction.

- The level difference between $n-e$ and s-w is about $10.0 \mathrm{~m}$

- There are natural contours as well as manmade contours in the form of grass slope.

- The temple is built on the highest area of the site.

\section{CONCEPT}

- The concept of the temple is external difference between the various temples, they all show meaningful and sacred symbols common to all Indian's religions.
- These are the symbols which have emerged in other countries and religions. One of these symbols is scared flower of the Indians: The Lotus Flower.

- Fariborz Sahba developed the project for the temple inspired from the concept of flower which is symbolises for purity. Cleanliness in Hindu tradition. The plans for the temple took two and half years to complete.

- In The Lotus Temple each component is repeated nine times.

\section{CONSTRUCTION SYSTEM}

- The lotus temple is constructed based on the arcaded construction system.

- $\quad$ Based on 9 radial grids.

- The Lotus Temple in which the structure of inner leaves enclose the interior dome in a canopy made of crisscrossing ribs and shells of intricate pattern.

- When views from inside each layer of ribs and shells disappears as it rises, behind the next, lower layer.

\section{STRUCTURAL DETAILS}

The complexity of the structure and the high level of labour necessary required a dynamic management with high grade of innovation. One of the essential means of achieving the fixed objective was to anticipate problems in advance and to resolve them using test and Models.
A. Part of structure
a. Basement
b. Three groups of Nine shells springing from the podium
c. Double layered Interior Dome
d. Nine Arches
e. Nine Ponds
f. Walkways

B. Ancillary Building Consisting of

a. Information center

b. Library

c. Administrative Building

d. Rest Rooms

\section{Component of Structure} GEOMETRY

By the help of geometry problem this typical structure design.

- The architect conceived the beautiful concept of the lotus, had to be converted/transfer into definable geometrical shapes such as spheres, cylinders, toroids and cones.

- The structure shapes were translated into equations, which were then used as a basis for structural analysis and engineering drawings.

- The resultant geometry of structure was so complex.

- The designers took over two and half years to complete the detailed drawings of the Lotus Temple.

- Complex geometry in simple terms describe below such as: 
a. Entrance leaves and outer leaves

- The surfaces created by the shell on each side of the entrance-ways and the outer leaves are formed by spheres of different radii, with their centres located at different points of the interior of the building. There is a group of spheres for the leaves of the entrance, some of which define the interior surfaces and others which define the exterior surfaces of the shells. The diameters of the spheres have been fixed to satisfy the structural consideration of the varying thicknesses of the petals.

- For the outer leaves, another group of spheres define the interior and exterior surfaces of the shells, but in this case the thickness of the shell is uniform: $1.33 \mathrm{~m}$ thick toward the lower part and $2.55 \mathrm{~m}$ toward the upper extreme.

- The structure of outer leaf in the entrance zone to the temple is $15.4 \mathrm{~m}$ wide and rises $22.5 \mathrm{~m}$ above the podium.

- The structure of the interior is $18.2 \mathrm{~m}$ wide in the entrance area and rises $7.8 \mathrm{~m}$ above the level of the podium.

\section{b. $\quad$ The Inner leaves}

- The structure of the inner leaf, comprising a cusp (ridge) and a re-entrant (valley).

- The structure of the inner leaves rise to an elevation of $34.3 \mathrm{~m}$ above the inner podium

- $\quad$ In The Lotus Temple at the lowest level each shell has a maximum width of $14 \mathrm{~m}$.

- It is uniformly $200 \mathrm{~mm}$ thick.

c. The Arch

- The Arches play important role in lotus temple because almost the entire structural load of the temple's interior space is supported by nine arches which spread out around the central hall, located at angular intervals of $40^{\circ}$.

- The lotus temple forms of these arches are created by flat, conical and cylindrical surfaces.

- $\quad$ In the lotus temple the intersection of these surfaces presents interesting contours and considerably improves the beauty of the arches.

- $\quad$ The nine arches bear almost the entire load of super structure beams were dew edged, leaving the central hub supported.

d. The Interior Dome

- In the interior dome structure three ribs spring from the crown of each arch.

- Up to certain height, the space between the ribs is covered by two layers of $60 \mathrm{~mm}$ thick shells

- In the interior dome structure other radial ribs rise from each of these intersections and all meet at the centre of the dome.

- While the central one (the dome rib) rises radially towards the central hub, the other two (the base ribs) move away from the central rib and intersect with similar base ribs of adjacent arches, thus forming an intricate pattern.

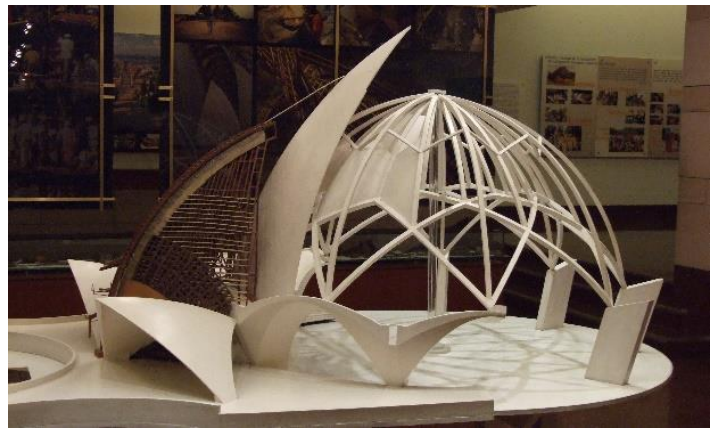

Fig: 6. Model of the temple at the Information centre

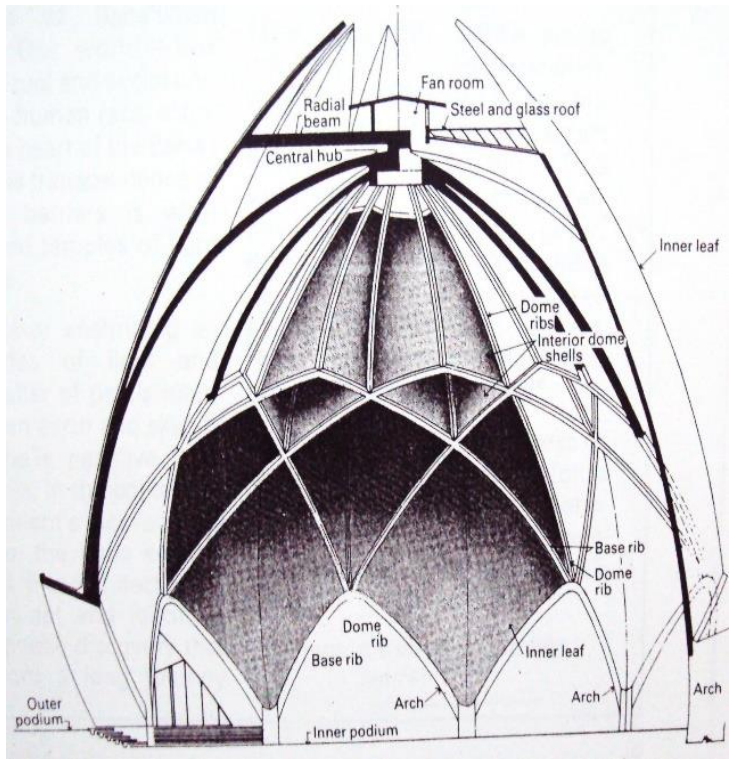

Fig: 7. Section Showing Interior Dome

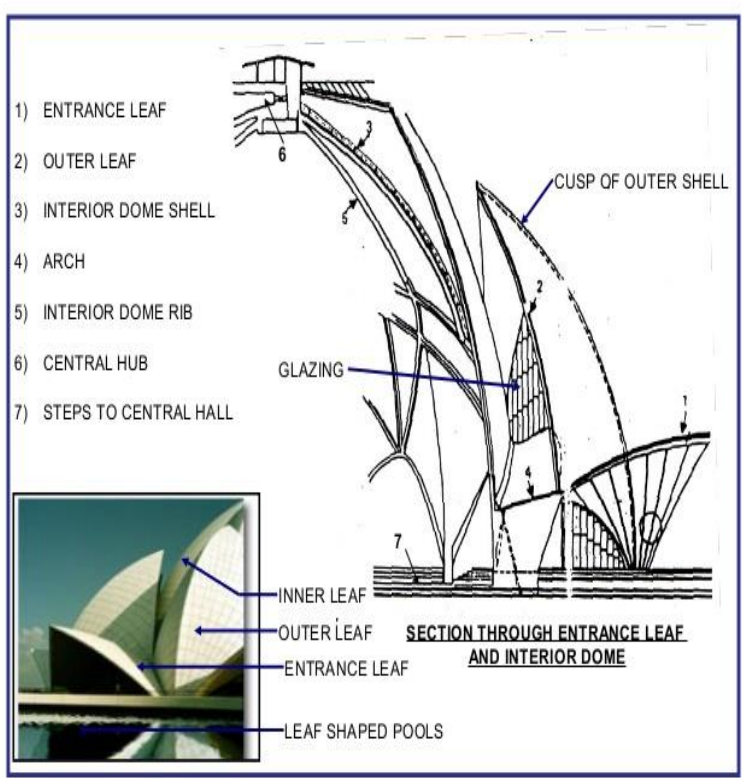

Fig: 8. Height of Petal 


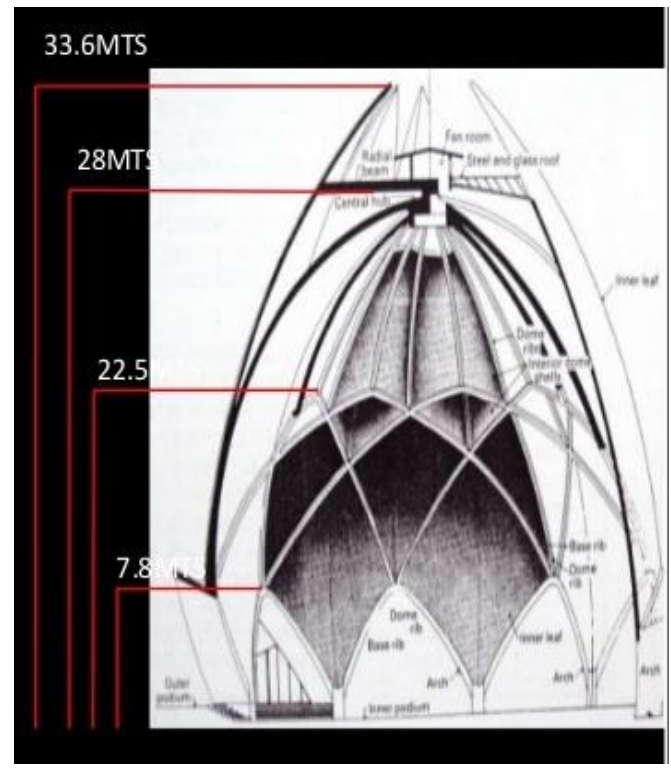

Fig: 9. Section through Entrance Leaf and Interior Dome

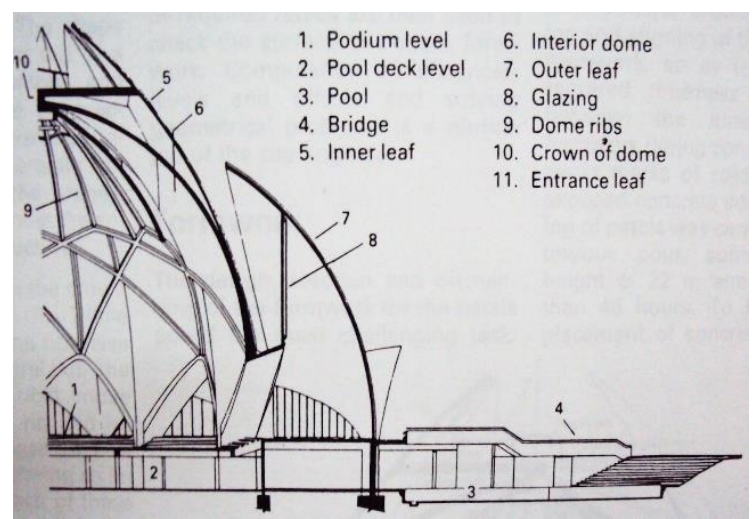

Fig: 10. Lotus Temple Structure Detail

\section{$>$ ANALYSIS \& DESIGN OF STRUCTURAL \\ COMPONENT}

- The Lotus Temple structure spherical surfaces for the Entrance \& Outer leaves.

- $\quad$ Arch soffits have a Parabolic cone shape

- $\quad$ Spheres, cylinders, toroids \& cone for inner leaves

- Nine interesting spheres from interior dome

- Final geometrically converted shapes were so complex that it took the designer over two \& a half years to complete the detailed drawings of the temple.

- In-situ reinforcement concrete construction

- $\quad$ Guniting

- Interior dome is $28 \mathrm{~m}$ is height and $34 \mathrm{~m}$ in diameter.

- The structure of Inner leaves are of $200 \mathrm{~mm}$ thick and of $33.6 \mathrm{~m}$ in height.

- $\quad$ The structure of Outer leaves are of $135 \mathrm{~mm}$ from their cusps to the line of glazing, beyond which they thicken to $250 \mathrm{~mm}$ and of $22.5 \mathrm{~m}$ in height.

- $\quad$ The structure of Entrance leaves are of $150 \mathrm{~mm}$ at center to $300 \mathrm{~mm}$ thick at their edges and of $7.8 \mathrm{~m}$ in height.
The structure of Shells within the interior dome: 60 mm thick.

$\begin{array}{ll}> & \text { Lotus Temple Designed for } \\ \text { a. } & \text { Dead load } \\ \text { b. } & \text { Live load } \\ \text { c. } & \text { Wind load }\end{array}$

Wind Tunnel test in Aeronautical Engineering Department at Imperial College, London

d. Earthquake load

$>\quad$ Lotus Temple is Designed By

a. Tubular steel glazing frames

b. Finite Element Analysis

c. Equivalent grillage models for shells in the computer program

d. Quadrilateral element

\section{MATERIALS}

- The Inner surface of all the shells have a uniform, bush-hammered, exposed concrete surface with architectural patterns

- $\quad$ For the inner leaves, these pattern were formed out of radial and vertical planes intersecting the surface of torus.

- For the outer and entrance leaves, and the interior dome, the patterns were formed out of longitudes and latitudes of sphere.

- The Lotus Temple structure formwork was designed in a manner that timber joist support the panel instead of the regular pattern of the structural steel supporting members of the structural steel supporting members of the space frame.

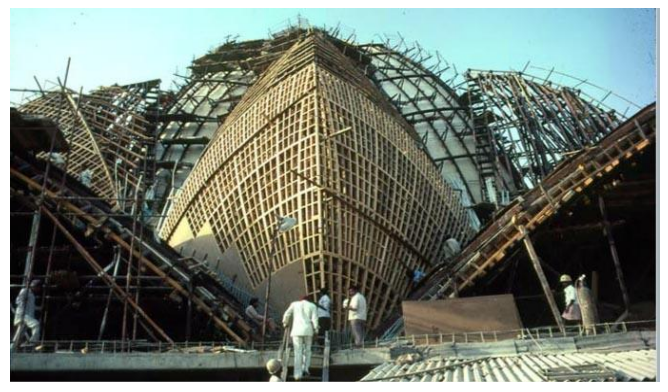

Fig: 11. Formwork

- In the lotus temple Full-scale mockups of the bottom surface of each of the shells were first made at ground level and the architectural patterns marked on this surface.

\section{CONCRETE}

- In The Lotus Temple all the ribs and shells up to radial beam level are in white concrete.

- To avoid crazing and shrinkage cracks in lotus temple structure, a mix of M30 Grade white concrete was designed.

- The entire quantity of white cement for lotus temple was therefore imported from Korea. 
- $\quad$ Specially graded dolomite aggregates were procured from Alwar mines near Delhi and white silica sand from Jaipur.

- Water/cement ratio: 0.43

- Slump achieved was in the range of 70-100 mm.

- Bush hammered finish for interior dome, inner and outer leaves.

- $\quad$ Concrete was drum mix on site.

- $\quad$ Three inner leaves at $120^{\circ}$ spacing, were concreted at a time, in only two lifts from their bases to the level of the star beams above.

- Outer and Entrance leaves were concreted in a continuous operation one at a time, using the removable outer shutter panels for access for concrete and vibrators to avoid cold joints.

- Concreting time for an outer leaf of lotus temple was of the order of 48 hours.

- Ice melt water was used in the mix to take care of the hot weather in Delhi to cool the concrete, that brought down temperature of concrete from $40^{\circ} \mathrm{C}$ to $25^{\circ} \mathrm{C}$.

- Systems of horizontal sprinkler pipes were used in curing.

\section{REINFORCEMENT}

- The structure of lotus temple petals were reinforced with $300 \mathrm{t}$ of galvanized bar to avoid the risk of rust staining and cracking and to maintain the pristine appearance of this monumental structure.

- The Lotus Temple structure in which the reinforcement used in the white concrete shells as well as the binding wires was entirely galvanized so as to prevent the longterm effect of rusting of reinforcement on the white concrete. Since galvanized reinforcement for concrete is seldom used in this country, several tests were carried out to ensure that the mechanical properties of reinforcement did not become adversely affected due to galvanizing.

- In the lotus temple structure to avoid the impression of cover blocks on the exposed surface of the shells, the inner layer of reinforcement was held in position by special steel spacers supported from the outer formwork.

\section{CONSTRUCTION}

Sequence

In the starting of construction basement and the interior podium were first built. From there, to raise the arches and shells, the structure was divided in parts, bearing in mind that when the formwork was removed, the constructed part would support itself until the next part was complete. The structure was divided in the following way:

\section{- Arches \\ - Inner leaves, radial beam \& central axis \\ - Interior Dome \\ - $\quad$ Access \& outer leaves \\ - $\quad$ Staging \& Formworks}

\section{CONSTRUCTION CHALLENGES}

- Excavation were undertaken by Ahlwalia Construction Company.
- $\quad$ Primary support to the formwork for the shells, dome, arches, were designed by the contractor and constructed of welded steel.

- Plywood form.

- Purlins.

- $\quad$ The Lotus Temple structure related Forms and their supports for the all shells were designed withstand pressure from continuous concreting and the outer forms were placed as concreting proceeded.

- The structure of three inner leaves were concreted at a time, generally in only two lifts.

\section{MARBLE CLADDING}

- Lotus Temple in which the Shells \& arches are clad in white Greek Marble panels, performed in Italy to the surface profile and to patterns related to the geometry by Marmi Vicentini S.P.A Company.

- The lotus temple in which the panels are fixed by means of stainless steel brackets secured by bolts in holes drilled after concreting and the joints were filled with moulded rubber cordon \& silicon sealant was applied over it.

- Floor finishes were also of white marble.

- Balustrades, stairs were precast

- Stones used for stairs were made of red sandstone.

- Complete construction of the structure was completed in the year 1986.

\section{CONCLUSION}

- Lightening and Natural ventilation used in the building.

- The structure of lotus temple is very typical and complex.

- High standard of quality demanded at the time of construction.

- The work is very innovative so the skills worker and labour used at the time of construction.

- The complete structure is both Architectural and Engineering point of view Wonderful and Marvel.

\section{ACKNOWLEDGEMENT}

The case study paper write on the topic of "case study of architecture structure of lotus temple" is suggested by Er. Prafull Kothari (Assistant Professor). Er. Prafull Kothari sir gave the idea about how to write the case study paper, what include in case study paper and help him to complete the paper. Suggest the internet site by the help of sir this case study paper complete.

I would like to express my gratitude to Er. Prafull Kothari sir who gave me the possibility to complete this paper and encouraged me to go ahead with this paper.

So, Mr. Prafull Kothari sir is acknowledge for the support, suggestion and help.

\section{REFERENCE}

a. https://www.slideshare.net/hamzaaaaaah/lotus-temple-30764589

b. https://en.wikiarquitectura.com/building/lotus-temple-bahaihouse-of-worship/

c. http://www.bahaihouseofworship.in/architectural-blossoming 
d. http://www.architecture-student.com/architecture/lotus-templedelhi-innovation-in-architecture/

e. https://www.galvanizedrebar.com/project/lotus-temple/

f. https://www.slideshare.net/mobile/bshreya62/lotus-temple1 ?sa $=$ X\&ved=2ahUKEwjIl7WanP7oAhVxIbcAHeobB oQ9QF6BAgFEAI

\section{AUTHOR BIOGRAPHY}

\section{Er. MOHAMMED SAHIL}

Civil Site Engineer, Parikshan Laboratory Material Testing Solutions, Indore, M.P. India

\section{2.}

Er. PRAFULL KOTHARI

Assistant Professor, Department Of Civil Engineering, SS

College Of Engineering, Udaipur, Rajasthan, India 